\title{
Density of Aedes Aegypti Larvae Based on The Knowledge, Attitude and Action of The Manager and the Conversion in Al-Markaz Al-Islami Mosque, Makassar City
}

\author{
Muh. Kamil Muh. Arief ${ }^{1}$, Erniwati Ibrahim ${ }^{1}$, Wahiduddin ${ }^{2}$,Hasanuddin Ishak ${ }^{1}$, Anwar \\ Mallongi ${ }^{1}$, Darmawansyah ${ }^{3}$ \\ ${ }^{I}$ Departemen of Environmental Health, Faculty of Public Health, Hasanuddin University, Indonesia. \\ ${ }^{2}$ Epidemiology Department, Faculty of Public Health, Hasanuddin University, Indonesia \\ ${ }^{3}$ Department of Health Administration and Policy, Faculty of Public Health, Hasanuddin University,
} Indonesia

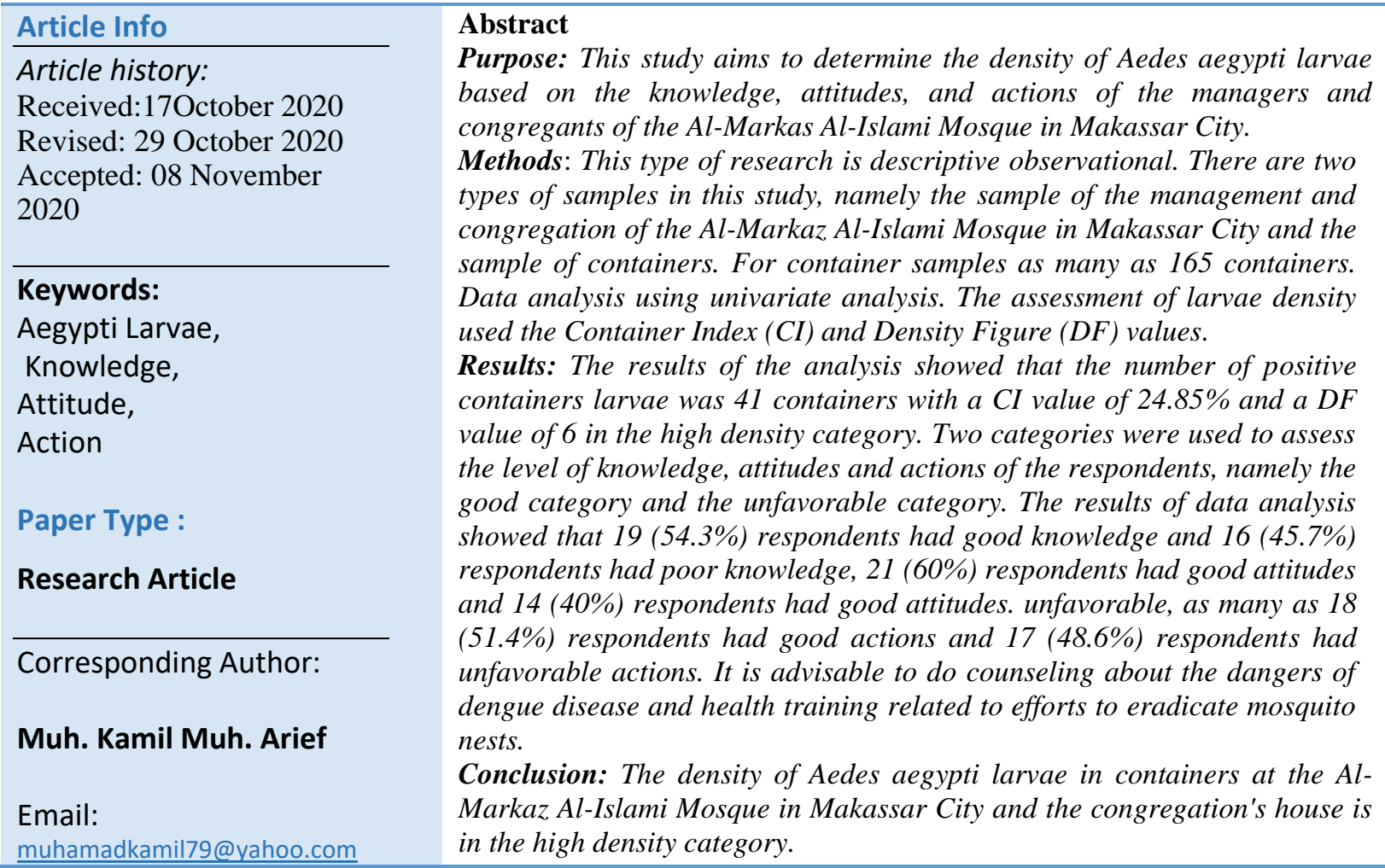

\section{Introduction}

Dengue Hemorrhagic Fever (DHF) is a disease caused by infection with the Dengue virus transmitted through the bite of the Aedes aegypti mosquito which is characterized by sudden fever, headache, back pain in the eye, nausea, and bleeding manifestations such as a positive tourniquet (rumple lead) test, freckles, Red spots on the skin (petekie), nosebleeds, and bleeding gums. Arbovirus disease, especially dengue fever is still a public health problem and has social and economic impacts. The social losses that occur include, among others, causing panic in the family, the death of family members, and a reduction in the life expectancy of the community (Ariani, 2016). 
Indonesia is a dengue endemic area, where the cases of DHF in the last five years have fluctuated, namely in 2014 as many as 100,347 cases with an incidence rate (IR 39.83 / 100,000 population) and a case fatality rate of 907 people (CFR 0, 9\%), in 2015 it increased by 129,650 cases (IR50.75 / 100,000 population) and the death rate was 1,071 people (CFR0.83\%), then in 2016, it increased again to 204,171 cases (IR 78.85 / 100,000 population). 1,598 people died (CFR 0.78\%). DHF cases from 2017 to 2018 experienced a decrease, where in 2017 there were 68,407 cases, (IR 26.10 / 100,000 population) the number of deaths was 493 people (CFR $0.72 \%$ ), and in 2018 decreased by 53,075 cases (IR20.01 / 100,000 population), the number of deaths 344 people (CFR 0.65\%). However, dengue cases that occur in Indonesia are still quite large and become a national problem (Kementerian Kesehatan, 2019).

Based on data from the South Sulawesi Provincial Health Office in 2016 and 2017, it was found that DHF cases in South Sulawesi Province had increased significantly, the number of cases in 2016 was 1,715 cases (IR 19 / 100,000 population) with 11 deaths. people (CFR $0.64 \%$ ), to 7,685 cases (IR $90 / 100,000$ population) with 38 deaths (CFR0.49\%). In 2018 there was a decrease in cases of 2,122 cases (IR 24 / 100,000 population) and the number of deaths by 19 people (CFR 0.9\%). Specifically for Makassar City, in 2018 the number of dengue cases was 256 and spread in all working areas of Puskesmas in Makassar City. The Puskesmas with the highest DHF cases were in Sudiang Puskesmas with 12 cases, then Puskesmas Paccerakkang and Puskesmas Kassi - Kassi each with 11 cases.

The Al-Markaz Al-Islami Mosque in Makassar City is included in the working area of the Malimongan Baru Community Health Center, where according to data from the Puskesmas, the last three years have seen dengue cases in the Malimongan Baru Community Health Center working area. In 2018 there were 9 cases of DHF, in 2019 there were 6 cases of DHF and in the period from January to May 2020 there were 3 cases of DHF. Factors contributing to the increase in dengue cases include vector density, population density which continues to increase in line with the development of residential areas, uncontrolled urbanization, increased transportation facilities (land, sea and air), the behavior of people who are less aware of environmental cleanliness, and climate change (Utami, 2015).

Research on potential sites for larvae breeding conducted by Pohan (2016), found that most types of larvae found in water reservoirs in public places, namely Aedes aegypti. The results of Malonda's (2016) study on a survey of DHF larvae in public places found that the density of Aedes aegypti larvae was quite high with a larva free rate (ABJ) of $71.4 \%$, far below the $95 \%$ national ABJ standard. The need to know the density of Aedes aegypti larvae based on the knowledge, attitudes and actions of the manager and congregation, which is to be a reference for early alertness to the transmission of dengue disease at the Al-Markas Al-Islami Mosque in Makassar City.

\section{Methods and Procedures}

This type of research is descriptive observational. This research was conducted at the Al-Markaz Al-Islami Mosque, Makassar City, South Sulawesi Province from July to September 2020. The population in this study were all managers registered at the Al-Markaz Al-Islami mosque in Makassar City and congregants who worship at the Al-Markaz Al-Islami

Copyright (c) 2020, Journal of Scientific Research in Medical and Biological Sciences (JSRMBS), Under 
mosque in Makassar City whose residence is around the Al-Markaz mosque. Markaz Al-Islami, namely in RT 02 and RT 03 in RW 02, Timungan Lompoa Village, Bontoala District, Makassar City, as well as all containers belonging to the Water Storage (TPA) and non-TPA groups located in the Al-Markaz Al-Islami mosque and in respondent's house. The number of management population is 52 people and the congregation is 163 people, so the total population of respondents is 215 people.

Sampling in this study was conducted using two methods, namely for the sample of respondents using purposive sampling method based on inclusion and exclusion criteria and for container samples using the total sampling method. The sample of the respondents consisted of 35 people, including 22 managers and 13 congregations. Meanwhile, the sample of containers was 165 containers. Primary data related to knowledge and attitudes were obtained using a questionnaire on PSN and for PSN action data obtained from direct observation of respondents. Data on density of Aedes aegypti larvae were obtained from direct observation on containers using visual methods with the help of tools in the form of flashlights and observation sheets. The size used is based on the value of the Container Index (CI) and the Density Figure (DF).

Secondary data related to DHF and Larva Free Rate (ABJ) were obtained from the South Sulawesi Provincial Health Office, the Makassar City Health Office and the Malimongan Baru Community Health Center as well as supporting data obtained from the Al-Markaz AlIslami Islamic Center Foundation and the Timungan Lompoa Village Office Bontoala District, Makassar City. The data analysis used in this research is univariate analysis which is used to determine the distribution of each variable under study. The data obtained is presented in tabular and narrative form to determine the proportion of each variable.

\section{Results and Discussion}

\section{Respondent Characteristics}

Table 1: Distribution of Respondent Characteristics by Age Group, Gender, Last Education

\begin{tabular}{l|c|c|c|c}
\hline \multirow{2}{*}{ Variable } & \multicolumn{2}{|c|}{ Respondent } & \multirow{2}{*}{$\mathbf{N}$} & \multirow{2}{*}{$\%$} \\
\cline { 2 - 3 } 1) Age & Administrator & Pilgrims & & \\
$21-30$ Years & 2 & 0 & 2 & 5,7 \\
$31-40$ Years & 11 & 3 & 14 & 40 \\
$41-50$ Years & 8 & 7 & 15 & 42,8 \\
50 Years & 1 & 3 & 4 & 11,4 \\
2) Sex & & & & \\
Male & 21 & 9 & 30 & 85,7 \\
Female & 1 & 4 & 5 & 14,3 \\
3) Education & 4 & & & \\
Elementary School & 7 & 5 & 9 & 25.7 \\
Junior School & 7 & 4 & 11 & 31.4 \\
High School & 4 & 3 & 10 & 28.5 \\
Higher Education & & 1 & 5 & 14.2 \\
\hline
\end{tabular}

Copyright (C) 2020, Journal of Scientific Research in Medical and Biological Sciences (JSRMBS), Under 


\section{Source: Data Analysis}

Based on Table 1, it can be seen that of the 35 respondents, the most number of respondents was 15 people aged 41-50 years (42.8\%) and the least was 21-30 years old, namely only 2 people $(5.7 \%)$. Male respondents were 30 people $(85.7 \%)$ and female respondents were 5 people $(14.3 \%)$. For the category of education level, the most respondents had SPM education, namely 11 people $(31.4 \%)$, and the least educated from tertiary education was 5 people $(14.2 \%)$.

Density of Aedes Aegypti Larvae Based on Knowledge, Attitudes and Actions of Managers and Congregations at the Al-Markaz Al-Islami Mosque in Makassar City

Table 2: Distribution of the presence of Aedes aegypti larvae in containers in Al-Markaz Al-Islami masjis Makassar city

\begin{tabular}{ccccc}
\hline Larvae Density & Mosque & Pilgrims House & $\mathbf{n}$ & $\boldsymbol{\%}$ \\
\hline Positive & 2 & 39 & 41 & 24,85 \\
Negative & 25 & 99 & 124 & 75,15 \\
\hline Total & $\mathbf{2 7}$ & $\mathbf{1 3 8}$ & $\mathbf{1 6 5}$ & $\mathbf{1 0 0}$ \\
\hline
\end{tabular}

Source: Primary data, 2020

Based on the table above, it can be seen that the total containers examined were 165 containers in the Al-Markas Al-Islami mosque in Makassar City and in the congregation's houses, both TPA (Final Processing Sites) and Non TPA, the number of positive containers larvae was 41 containers $(24.85 \%)$ and containers negative for larvae were 124 containers $(67 \%)$

Table 3: Distribution of Aedes aegypti Larvae Density Based on Container Type in the AlMarkaz Al-Islami Mosque, Makassar City

\begin{tabular}{|c|c|c|c|c|c|c|c|c|c|c|}
\hline \multirow{2}{*}{$\begin{array}{l}\text { Typeof } \\
\text { Container }\end{array}$} & \multicolumn{2}{|c|}{$\begin{array}{c}\text { Container } \\
\text { Layout }\end{array}$} & \multirow{2}{*}{$\sum_{\text {Container }}$} & \multirow{2}{*}{$\begin{array}{c}\% \\
\text { Kontainer }\end{array}$} & \multicolumn{6}{|c|}{ Positive Larva Containers } \\
\hline & Masjid & $\begin{array}{l}\text { Rumah } \\
\text { Jemaah }\end{array}$ & & & $\begin{array}{l}\text { Masjid } \\
\text { Mosque }\end{array}$ & $\begin{array}{c}\text { Respondent } \\
\text { House }\end{array}$ & $\begin{array}{c}\text { Total } \\
\text { Container }\end{array}$ & $\%$ & CI & DF \\
\hline Water tub & 21 & 16 & 37 & 22,42 & 2 & 4 & 6 & 3,6 & & \\
\hline Drum & 0 & 7 & 7 & 4,24 & 0 & 3 & 3 & 1,8 & & \\
\hline $\begin{array}{l}\text { Water } \\
\text { barrel }\end{array}$ & 2 & 21 & 23 & 13,94 & 0 & 7 & 7 & 4,2 & & \\
\hline Bucket & 4 & 38 & 42 & 25,45 & 0 & 10 & 10 & 6,1 & 24,85 & 6 \\
\hline Refrigerator & 0 & 31 & 31 & 18,79 & 0 & 8 & 8 & 4,8 & & \\
\hline Dispenser & 0 & 25 & 25 & 15,15 & 0 & 7 & 7 & 4,2 & & \\
\hline Total & 27 & 138 & 165 & 100 & 2 & 39 & 41 & 24,85 & & \\
\hline
\end{tabular}

Source: Primary data, 2020

Copyright (C) 2020, Journal of Scientific Research in Medical and Biological Sciences (JSRMBS), Under 
Table 2 shows the total containers inspected as many as 165 containers. The number of containers positive for Aedes aegypti larvae was 41 containers with a Container index (CI) value $=24.85 \%$ and a Density Figure $(\mathrm{DF})$ value $=6$ with a high density category. Where the type of containers that were positive for Aedes aegypti larvae were found, namely $6(3.6 \%)$ water tanks, $3(1.8 \%)$ drums, 7 (4.2\%) water barrels, $10(6.1 \%)$ buckets, 8 ( $4.8 \%)$ refrigerator and $7(4.2 \%)$ dispensers.

Table 4: Distribution of Knowledge, Attitudes and Actions of Managers and Congregations At the Al-Markaz Al-Islami Mosque in Makassar City Related to the Eradication of Mosquito Nests (PSN)

\begin{tabular}{cccc}
\hline Variable & Category & $\mathbf{N}$ & $\%$ \\
\hline \multirow{2}{*}{ Knowledge } & Good & 19 & 54,3 \\
& Less Good & 16 & 45,7 \\
Attitude & Good & 21 & 60 \\
& Less Good & 14 & 40 \\
Action & Good & 18 & 51,4 \\
& Less Good & 17 & 48,6 \\
\hline
\end{tabular}

Source: Primary data, 2020

Table 3 shows that 19 respondents $(54.3 \%)$ with good knowledge category, 16 respondents $(45.7 \%)$ with poor knowledge category, 21 respondents $(60 \%)$ with good attitude category, 14 respondents $(40 \%)$ with category unfavorable attitude, 18 respondents $(51.4 \%)$ with good action category and 17 respondents $(48.6 \%)$ with unfavorable action category.

Table 5: Distribution of Knowledge Relationships and Respondents' Attitudes Regarding the Eradication of Mosquito Nests (PSN)

\begin{tabular}{cccccccc}
\hline \multirow{2}{*}{ Crosstab } & Category & \multicolumn{9}{c}{ Attitude } & \multirow{2}{*}{ Total } & \% \\
\cline { 3 - 7 } & & Good & $\%$ & $\begin{array}{c}\text { Less } \\
\text { Good }\end{array}$ & $\%$ & & \\
\hline \multirow{2}{*}{ Knowledge } & Good & 10 & 28,6 & 9 & 25,7 & 19 & 54,3 \\
& Less Good & 11 & 31,4 & 5 & 14,3 & 16 & 45,7 \\
\hline \multicolumn{2}{c}{ Total } & 21 & 60 & 14 & 40 & 35 & 100 \\
\hline \multicolumn{2}{c}{ Source: Primary data, 2020 } & & & & & &
\end{tabular}

The data in table 5 above shows that of the 35 respondents studied, the most were found respondents with good knowledge and attitudes, as many as 10 people (28.6\%). And the least number of respondents who have poor knowledge and attitudes, namely 5 people $(14.3 \%)$.

Table 6: Distribution of Knowledge Relationships and Respondents' Actions Related to Eradication of Mosquito Nests (PSN)

\begin{tabular}{lllllll}
\hline \multirow{3}{*}{ Crosstab } & Category & \multicolumn{4}{c}{ Action } \\
\cline { 3 - 4 } & Good & $\%$ & $\begin{array}{c}\text { Less } \\
\text { Good }\end{array}$ & $\%$ & Total \\
\hline
\end{tabular}

Copyright (C) 2020, Journal of Scientific Research in Medical and Biological Sciences (JSRMBS), Under 


\begin{tabular}{cccccccc}
\hline \multirow{2}{*}{ Knowledge } & Good & 11 & 31,4 & 8 & 22,9 & 19 & 54,3 \\
& Less Good & 7 & 20 & 9 & 25,7 & 16 & 45,7 \\
\hline \multicolumn{2}{c}{ Total } & 18 & 51,4 & 17 & 48,6 & 35 & 100 \\
\hline
\end{tabular}

Source: Primary data, 2020

The data in table 5 above shows that of the 35 respondents studied, the most respondents were found with good knowledge and actions, namely 11 people $(31.4 \%)$. And the least of the respondents who have poor knowledge but have good actions, namely 7 people (20\%).

Table 7: Distribution of Respondents' Attitudes and Actions Relating to PSN

\begin{tabular}{cccccccc}
\hline \multirow{2}{*}{ Crosstab } & \multirow{2}{*}{ Category } & \multicolumn{6}{c}{ Action } \\
\cline { 3 - 6 } & & Good & $\%$ & $\begin{array}{c}\text { Less } \\
\text { Good }\end{array}$ & $\%$ & \multirow{2}{*}{ Total } & $\%$ \\
\hline \multirow{2}{*}{ Attitude } & Good & 12 & 34,3 & 9 & 25,7 & 21 & 60 \\
& Less Good & 6 & 17,1 & 8 & 22,9 & 14 & 40 \\
\hline \multicolumn{2}{c}{ Total } & 18 & 51,4 & 17 & 48,6 & 35 & 100 \\
\hline
\end{tabular}

Source: Primary data, 2020

The data in table 5 above shows that of the 35 respondents studied, the most respondents were found with good attitudes and actions, namely 12 people $(34.3 \%)$. And the least number of respondents who have bad attitudes but have good actions, namely 6 people (17.1\%).

\section{Discussion}

The density of Aedes aegypti larvae can be used to determine the critical threshold number which is a threat to the emergence of dengue fever disease. Larvae or larvae are an indicator of dengue transmission somewhere. There are several indicators for these larvae, namely: Larva Free Rate (ABJ), House Index (HI), Container Index (CI) and Breteau Index (BI). In determining whether an area is free or not, the indicator used is ABJ. Of the 100 houses examined that have larvae not more than 5\%. ABJ indicator is 95\%(Arsin, 2013).

In this study, the density of Aedes aegypti larvae which is used as a basis for thinking is the density of larvae which is described based on the Container Index (CI), with this index then correlated with the Density figure (DF) number set by WHO. From the results of the research conducted, it showed that from the 165 observed containers, the CI value was $24.85 \%$, so that the DF value was at number 6 , which is the high density category. From the research results, it can also be seen that the type of container, drums, water barrels and buckets, are most at risk of positive Aedes aegypti larvae. This is because the water vats, drums and buckets are located outside the house and they do not have covers. They are neglected and not regularly cleaned. Under these conditions, it is recommended that the container be covered so that it is not easy to become a breeding ground for Aedes aegypti larvae. In addition to this, it is also recommended to take preventive measures and eradicate mosquito nests through $3 \mathrm{M}$ plus activities regularly and continuously.

The existence of containers plays a very important role in the vector density of Aedes aegypti mosquitoes, because the more containers, the more breeding places and the denser the 
Aedes aegypti mosquito population. The denser the Aedes aegypti mosquito population, the higher the risk of being infected with the dengue virus with a faster spread time so that the number of dengue cases increases rapidly which in turn results in an outbreak. The main source of breeding of Aedes aegypti is water containers that are used for daily needs (Azlina \& Anas, 2016). Another factor that affects is environmental factors, where the high density of the mosquito population is caused by the large number of breeding places for mosquitoes that usually occur during the rainy season (Arsin et al, 2013).

The results of this study indicate that as many as 19 respondents $(54.3 \%)$ with good knowledge category and 14 respondents $(45.7 \%)$ with poor knowledge category. Knowledge is a variety of symptoms that humans encounter and acquire through sensory observation. Knowledge arises when someone uses their senses or reason to recognize certain objects or events that have never been seen or felt before (Meliono in Amalia, et al, 2018). Knowledge or cognitive is a very important domain for the formation of one's actions (ovent behavior). Lack of knowledge can affect the actions taken because knowledge is one of the predisposing factors for the occurrence of new behaviors.

Behaviors that are based on knowledge will last longer than those that are not based on knowledge (Notoatmodjo, 2003). WHO (2009) also reveals that a certain behavior is caused by thoughts and feelings in the form of knowledge, perceptions, attitudes, beliefs and judgments - one's assessment of objects. Therefore, knowledge of the dangers of Aedes aegypti mosquitoes and dengue disease makes a person aware that PSN (Mosquito Nest Eradication) is a step that must be taken to prevent the disease and motivate someone to do PSN properly. However, good knowledge cannot guarantee to have good behavior as well, but it depends on one's own awareness. One of the reasons for the low Larva Free Rate (ABJ) is the low awareness of PSN from the community (Ibrahimet al, 2019).

Research by Imam et al (2015) states that increasing knowledge can be done by getting health education or information from parents, teachers, mass and print media. In carrying out the training, apart from using the lecture method, also using presentation media in the form of videos. According to Daryanto's (2013) research, the selection of presentation media is presented in the form of combined text, images and animation. So that the use of presentation media is able to attract the attention of respondents in implementing health education so that it can increase respondents' knowledge.

Respondents who have a good level of knowledge actually practice PSN well when compared to respondents who have a low level of knowledge. In general, respondents who have a good level of knowledge are afraid of dengue transmission, so that respondents who have a good level of knowledge are more responsive and diligent in carrying out PSN activities. It can be seen that the more people who are highly knowledgeable about DHF and PSN, the more people will implement PSN practices well and sustainably. Research that is in line is the research conducted by Ishak et al (2018) which shows a relationship between the presence of Aedes aegypti larvae and the PSN DHF action and there is a relationship between the density of Aedes aegypti larvae and PSN DHF action.

The results of this study found that as many as 21 respondents $(60 \%)$ with a good attitude category and 14 respondents (40\%) with a bad attitude category. In accordance with Green's theory (2005) which states that attitude is a factor that plays a role in health behaviour. 
The more positive a person's attitude or views on something, the better the action he takes in that case. If the individual is completely free from all pressures or obstacles that can interfere with the expression of his attitude, then it can be expected that the form of behavior that appears as an actual form of expression. The emergence of will or will is an advanced form of awareness and understanding of objects in this case is the practice of PSN.

The relationship between knowledge and attitude is very continuous. The results of this study indicate that respondents who have good PSN knowledge also have good PSN attitudes more than respondents who have good knowledge but have bad PSN attitudes, namely 10 (28.6\%) respondents compared to $9(25.7 \%)$ respondents from a total of $19(54.3 \%)$ respondents. Respondents who have less good PSN knowledge but have good PSN attitudes are more than respondents who have poor PSN knowledge and also have poor PSN attitudes, namely $11(31.4 \%)$ respondents compared to $5(14.3 \%)$ respondents from a total of $16(45.7 \%)$ respondents. This is in line with research(Purnama, Satoto and Prabandari, 2013) shows that the level of knowledge and attitude has a meaningful relationship. This is because the vector of dengue fever and the level of public knowledge can play a very important role in dengue transmission. A good level of knowledge regarding the symptoms and signs of dengue fever is one way of treating DHF transmission (Pai, H.H., Lu, Y.L., Hong, Y.J. \& Hsu, 2005).

The results also showed that respondents who had good PSN knowledge and also had good PSN actions were more than respondents who had good PSN knowledge but had poor PSN actions, namely 11 people (31.4\%) compared to 8 people (22.9\%) ) from a total of 19 respondents (54.3\%). Respondents who had less good PSN knowledge and also had less good PSN actions were more than respondents who had poor PSN knowledge but had good PSN actions, namely 9 people (25.7\%) versus 7 people (20\%) of the total 16 people respondents (45.7\%). This is in line with research conducted by(Nur Aisah Nahumarury, 2013) which states there are still some people who have good knowledge, but lack action. And there are still people who have less knowledge, but their actions are good for PSN. From these data, it can be seen that there are still respondents who have good knowledge and have less actions that illustrate that there are still some people who do not care about the implementation of PSN. The community's willingness to take preventive action is needed to support programs implemented by the government. Community participation in maintaining health must extend from individuals, families, and the wider community (Departemen Kesehatan RI, 2001). Apart from willingness, another factor that affects knowledge is education. If we look at the characteristics of the respondents, many respondents have graduated from elementary school level, this indicates that people with low education may not understand PSN. This concurs with (Nahumrury, 2016) that there are $82 \%$ of people who have low education which results in bad behavior, so that they suffer more from DHF.

The results of the analysis between attitudes and actions show that respondents who have good PSN attitudes and also have good PSN actions are more than respondents who have good PSN attitudes but have less good PSN actions, namely 12 (34.3\%) respondents compared to $9(25,7 \%)$ of the total $21(60 \%)$ respondents. Respondents who have PSN attitudes are not good and also have less good PSN actions than respondents who have bad PSN attitudes but have good PSN actions, namely $8(22.9 \%)$ respondents compared to $6(17.1)$ respondents out of a total of $14(40 \%)$ of respondents. 
The results of cross tabulation between attitudes and actions from the research results there are still responsive ones who have good attitudes, but the actions towards PSN are still lacking, but there are responses who have bad attitudes, but the actions towards PSN are good. Lack of public attitude in efforts to eradicate mosquito breeding indicates that someone has a negative character, meaning that he will do something that is not good, and vice versa if someone has a positive attitude towards something that must be done. This is in line with research conducted by (Hasyim, 2016) There are still people who have negative attitudes and actions that are not good, and there are still respondents who have positive traits but have unfavorable actions.

Attitude is a reaction or response that is still closed and someone to a stimulus or object. The manifestation of attitude cannot be immediately seen, but can only be interpreted first and the behavior is closed. Attitude is not yet an action or activity, but it is a predisposition to the action of a behavior. Attitude is the readiness to react to objects in a certain environment as an appreciation of the object (Notoatmodjo, 2007). From the results of this study, it is also showed that as many as 18 respondents $(51.4 \%)$ with good action category and 17 respondents $(48.6 \%)$ with unfavorable action category. Respondents' actions towards efforts to eradicate mosquito nests, namely 3M (burying used goods, closing and draining water reservoirs) are whether or not health behaviors have been implemented in the form of measures to prevent and control dengue, namely by $3 \mathrm{M}$ in everyday life. Turisnawati's research (2016) shows that $60.7 \%$ of respondents have a low level of knowledge and $74.8 \%$ have insufficient action against the implementation of 3M Plus. Even so, $72 \%$ of respondents were kind.

\section{Conclusion}

Based on the results of this study, it can be concluded that the density of Aedes aegypti larvae in containers at the Al-Markaz Al-Islami Mosque in Makassar City and the congregation's house is in the high density category because it has a value of DF $=8$ based on the CI value $(24.85 \%)$. From a total of 165 containers that were examined, there were 41 containers that were positive for larvae. It is revealed that more respondents have good PSN knowledge about Mosquito Nest Eradication (PSN) knowledge, namely 19 (54.3\%) compared to 16 (45.7) respondents. In terms of attitude, the respondents have good PSN attitudes, namely $21(60 \%)$ of respondents compared to $14(40 \%)$ of respondents. The respondents who have good PSN actions are more than the respondents who have less good PSN actions, namely 18 $(52.4 \%)$ respondents compared to $17(48,6)$ respondents. It is recommended that counselling about the dangers of dengue disease and health training related to PSN be carried out in an effort to prevent the occurrence of dengue cases at the Al-Markaz Al-Islami mosque in Makassar City.

\section{Conflict of Interest}

The authors of the article declare no conflict of interest.

\section{Funding:}

Copyright (C) 2020, Journal of Scientific Research in Medical and Biological Sciences (JSRMBS), Under 
The authors received no funding for conducting this study.

\section{References}

Amalia L \& Efphi, H. (2018). The Relationship between Knowledge and Attitudes in the Implementation of Kangaroo Care Method.JPKI. 4(2):20-27.

Ariani A.P.(2016). Dengue Hemorrhagic Fever. Yogyakarta: Nuha Medika.

Arsin, A. A. (2013). Epidemiology of Dengue Hemorrhagic Fever (DHF) in Indonesia. Makassar: Masagena Press

Arsin, A. A., Ibrahim, E., Ane, R., \& Ishak, H. (2013). Analysis of Environmental Factors and Movement of PSN DBD Against Density of Aedes aegypti Mosquito Larva and DHF Incidence in DHF Endemic Areas in Makassar City. [online]. http://repository.unhas.ac.id/handle/123456789/11700 [accessed 29 October 2020]

Azlina, A., \& Anas. (2016). The Relationship between Mosquito Nest Eradication Measures and the Existence of DHF Vector Larvae in Lubuk Buaya Village. Jurnal Kesehatan Andalas.

Daryanto.(2013). Strategy and Teaching Stages. Bandung: CV Yama Widya

Ministry of Health of the Republic of Indonesia. (2001).Riset Kesehatan Dasar Republik Indonesia. Jakarta.

Dinas Kesehatan Kota Makassar.(2018). DHF Cases Per Puskesmas Makassar City Health Office. Kota Makassar, Indonesia.

Dinas Kesehatan Provinsi Sulawesi Selatan. (2018). Situation of Monthly DHF Cases by Regency / City of South Sulawesi Province. South Sulawesi Provincial Health Office: Indonesia.

Green L.W. (2005). Health Education Planing, A Diagnostic Approach. Washington: Moefield Publising Company.

Hasyim, D. M. (2016). Factors Associated with the Eradication of Dengue Hemorrhagic Fever Mosquito Nests (PSN DBD) Jurnal Kesehatan, 4(2).

Ibrahim, E., Manyullei, S., \& Sumarni., (2019). Study on the existence of Aedes aegypti larvae before and after the PSN DBD intervention in Pandang Village, Panakkukang District, Makassar City. Jurnal Nasional Ilmu Kesehatan (JNIK), 2(2), hal 109-120

Imam, Arif, Melly, Prabawati, Tarma. (2015). Adolescent Knowledge Level About Reproductive Health, 1(2).

Ishak, H., Toding, N., Natsir, M. F., \& Amqam, H. (2018). Description of Aedes aegypti Larva Density Based on Mosquito Breeding Eradication Action in the Dengue Endemic Rappocini Sub-District Makassar. Proc. ICER-PH, Makassar, Indonesia. 26-27 Oktober 2018

Kementerian Kesehatan RI. (2019). Indonesia Health Profile 2018. Jakarta : Indonesia .

Kementerian Kesehatan. (2019). Indonesia Health Profile 2018 [Indonesia Health Profile 2018].

Maksud M. (2016). Survey of DHF larvae in public places (TTU) in Tanantovea District, Donggala Regency, Central Sulawesi. Jurnal Vektor Penyakit.9(1):9-14.

Copyright (C) 2020, Journal of Scientific Research in Medical and Biological Sciences (JSRMBS), Under 
Nahumrury, N. A. (2016). Knowledge, Attitudes and Measures to Eradicate the Nest of Aedes Aegypti Mosquitoes with Larvae in the Kassi-Kassi Village, Makassar City. Media Kesehatan Masyarakat Indonesia, 9(3), 147-152.

Notoatmodjo S. (2003). Health Behavior and Education.Jakarta : PT. Rineka Cipta.

Notoatmodjo S. (2007). Health Promotion and Behavioral Sciences. Jakarta : Rineka Cipta.

Nur Aisah Nahumarury (2013) 'Aedes Aegypti Mosquito Nests With Larvae Presence in KassiKassi Village, Makassar City Knowledge, Attitudes, Aedes aegypti Mosquito Nest Eradication and Larval', (September), pp. 147-152.

Pai, H.H., Lu, Y.L., Hong, Y.J. \& Hsu, E. (2005) 'The differences of dengue vectors and human behavior between families with and without members having dengue feve', International journal of Environmental Health Research, 15, pp. 263-269.

Pohan N.R., Wati N.A.P.\& Nurhadi M..(2016). Description of Density and Potential Breeding Sites of Aedes sp. In Public Places in the Work Area of the Umbulharjo I Health Center, Yogyakarta City. Jurnal Formil KesMas Respati.1(2):109-120.

Purnama, S., Satoto, T. and Prabandari, Y. (2013) "Knowledge, Attitudes and Behavior to Eradicate Mosquito Nests Against Dengue Infection in South Denpasar District, Denpasar City, Bali", Archive of Community Health, 2(1), pp. 20-27.

Turisnawati Y. (2016). Implementation of Community Behavior-Based Dengue Hemorrhagic Mosquito Nests Eradication in Kalipancur. AIPKEMA .

Utami. (2015). The Relationship between Knowledge and Community Actions and the Incidence of Dengue Hemorrhagic Fever (DHF) (Study in Putat Jaya Sub-District, Surabaya, 2010-2014). Jurnal Berkala Epidemiologi. 242-253.

WHO.(2009). Complete Guide to Prevention and Control of Dengue Hemorrhagic Fever.Jakarta: EGC. 